\title{
Sustainable Development Goals Synergies/Trade-offs: Exploring Long- and Short-Run Impacts of Economic Growth, Income Inequality, Energy Consumption and Unemployment on Carbon Dioxide Emissions in South Africa
}

\author{
Bertrand Tessa Ngankam ${ }^{1}$ \\ ${ }^{1}$ Financial Economic Program, American University, Washington DC, United States \\ Correspondence: Bertrand Tessa Ngankam, Financial Economic Program, American University, 4400 \\ Massachusetts Avenue NW, Washington DC 20016, United States. E-mail: bertrand.tessa2@gmail.com
}

Received: October 24, 2018

Accepted: July 8, 2019 Online Published: July 30, 2019

doi: $10.5539 /$ jsd.v12n4p40

URL: https://doi.org/10.5539/jsd.v12n4p40

\begin{abstract}
This study examines the short- and long-run impacts of economic growth and unemployment (SDG 8), energy consumption (SDG 7) and income inequality (SDG 10) on $\mathrm{CO}_{2}$ emissions in South Africa over the period 1980-2012 to establish potential synergy/trade-off to achieve these goals. We use the autoregressive distributed lag (ARDL) approach to cointegration technique. Our results show that the promotion of economic growth (SDG 8) as well as the reduction in energy consumption/increase in energy efficiency (SDG 7) can be achieved in synergy with the reduction of $\mathrm{CO}_{2}$ emissions (SDG 13). On the other hand, our results suggest a trade-off between reducing unemployment rate or achieving productive employment and decent work (SGD 8) and mitigating $\mathrm{CO}_{2}$ emissions (SDG 13). Neither a synergy nor trade-off (neutral relationship) is found between the reduction of income inequality (SDG 10) and the reduction of $\mathrm{CO}_{2}$ emissions (SDG 13). Our findings highlight the importance of mainstreaming SDG's policy interactions to achieve sustainable development goals, while also stressing the potential for South Africa to achieve low-carbon development should economic growth be decoupled from carbon-intensive energy use through policies that promote access and effective use of clean energy. The transition to clean energy is therefore emphasized and relevant factors underpinning such as transition should be explored further.
\end{abstract}

\section{Highlights}

- This study examines the short- and long-run impacts of economic growth and unemployment (SDG 8), energy consumption (SDG 7) and income inequality ( $\mathrm{SDG} 10$ ) on $\mathrm{CO}_{2}$ emissions in South Africa

- The autoregressive distributed lag approach to cointegration is employed

- A synergy is established between the promotion of economic growth (SDG 8) and the reduction of $\mathrm{CO}_{2}$ emissions (SDG 13), and between the reduction in energy consumption/increase in energy efficiency (SDG 7) and the reduction of $\mathrm{CO}_{2}$ emissions (SDG 13)

- A trade-off is confirmed between reducing unemployment rate or achieving productive employment and decent work (SDG 8) and mitigating $\mathrm{CO}_{2}$ emissions (SDG 13)

- A neutral relationship is found between the reduction of income inequality (SDG 10) and the reduction of $\mathrm{CO}_{2}$ emissions (SDG 13)

- Policymakers need to mainstream SDG's policy interactions to achieve sustainable development goals

- South Africa can achieve low-carbon development should economic growth be decoupled from carbon-intensive energy use through policies that promote access and effective use of clean energy

Keywords: carbon dioxide emissions, sustainable development goals, South Africa

\section{Introduction}

An important challenge to the international development community is to design comprehensive development policies that simultaneously address each and every development issue in a manner that maximizes synergies 
and/or minimizes trade-offs. The Sustainable Development Goals (SDGs), a collection of 17 goals and 169 targets set by the United Nations in 2015 as a universal call to action to end poverty, protect the planet and promote peace and prosperity, are not immune to this challenge. While each SDG is presented independently, there is a large consensus among scholars (e.g., Singh et al., 2018; Pradhan et al., 2017; Nilsson et al., 2016) that they are interrelated and interconnected issues and that conflicting interactions among them may result in trade-off, whereas complementary ones may provide opportunity for co-benefit or synergy. Understanding the nature of such relationship is therefore crucial to effectively implement SDGs-related policy. This is specifically the case in the current context marked by the need to combat climate change (SDG 13), one of the most entrenched and interconnected issues under the SDGs.

Over the last two decades, the relationship between carbon dioxide $\left(\mathrm{CO}_{2}\right)$ emissions, a proxy for climate change, and other SDGs has been intensively assessed by researchers. For example, Kais and Hammami (2016) report 26 research studies on the impact of economic growth (Note 1) (SDG 8) on $\mathrm{CO}_{2}$ emissions over the period 2003-2014, whereas Grunewald et al. (2017) report five studies on the relationship between income inequality (Note 2) (SDG 10) and $\mathrm{CO}_{2}$ emissions up to 2016. Exploring the potential synergies/trade-offs between the SDGs, and specifically the inter-relation with $\mathrm{CO}_{2}$ emissions has significant policy importance. A recent IPCC Special Report on Global Warming of $1.5^{\circ} \mathrm{C}$ indicates that the avoided climate change impacts on sustainable development would be greater if synergies are maximized while trade-offs are minimized (IPCC 2018). As a framework for this analysis, we posit that synergy is materialized when: economic growth (a proxy for SDG 8) is achieved alongside a reduction in $\mathrm{CO}_{2}$ emissions (a proxy for SDG 13); energy efficiency or low energy consumption (a proxy for SDG 7) is associated with $\mathrm{CO}_{2}$ emissions reduction; reduction in income inequality (a proxy for SDG 10) leads to a decrease in $\mathrm{CO}_{2}$ emissions; decrease in unemployment rate (a proxy for SDG 8) is related to a decrease in $\mathrm{CO}_{2}$ emissions. Otherwise, we conclude that a trade-off relationship applies and if neither synergy nor trade-off exist, a neutral relationship ensues.

A review of the existing literature on the impacts of economic growth and unemployment (SDG 8), energy consumption (SDG 7) and income inequality (SDG 10) on $\mathrm{CO}_{2}$ emissions provides mixed results, pointing to different mechanisms and effects. The aim of this paper is to contribute to this body of literature in the specific context of South Africa. These linkages have been largely overlooked and unanswered for policy-making in South Africa and this paper attempts to provide robust findings to better mainstreaming climate change into sustainable development policy. Specifically, the paper examines the long- and short-run impacts of economic growth and unemployment (SDG 8), energy consumption (SDG 7) and income inequality (SDG 10) on $\mathrm{CO}_{2}$ emissions in South Africa to establish potential synergy/trade-off to achieve these goals. To our knowledge, this is the first study to investigate such a relationship in the specific context of South Africa, especially from the synergy and trade-off relationship standpoint. The rest of this paper is organized as follows: Section 2 provides a brief review of the literature. Section 3 describes the econometric methodology and Section 4 presents the data used for this study. The long- and short-run relationships are analyzed in section 5 followed by discussions. The conclusion and policy implications are outlined in Section 6.

\section{Brief Review of the Literature}

This brief review of the literature gives a general context about what makes South Africa a good candidate for this study, then provides an overview of the empirical literature about the impacts of the sustainable development goals being considered on $\mathrm{CO}_{2}$ emissions.

\subsection{What Makes South Africa an Interesting Case?}

What makes South Africa an interesting case in respect to the relationship between $\mathrm{CO}_{2}$ emissions and the other SDGs is as follows: First, South Africa is the second-largest economy in Africa after Nigeria and one of the only four upper-middle-income economies in Africa - alongside Botswana, Gabon and Mauritius - with a GDP estimated at $\$ 349.3$ billion in 2017. South Africa is one of the major emitters of $\mathrm{CO}_{2}$ in the world, accounting for about 1-percent of the world total emissions. South Africa's economy is heavily dependent on the energy sector, which accounts for 15-percent of the GDP. A large majority of the primary energy (about 77-percent) is provided by the coal industry, whose activities represent about 87-percent of total $\mathrm{CO}_{2}$ emissions (Shahbaz et al., 2013; Winkler, 2007). South Africa is the most unequal country in the world. Income inequality (Gini coefficient of 0.63 in 2015) is very high and due to a combination of two factors. The White population, which represents only about 10-percent of the working force, makes nearly three times the average wage of Black South Africans, who represent nearly three-quarters of the entire work force (World Bank, 2018). Unemployment is among the highest in the world, around 27-percent of the workforce and significantly higher among the black youth. All these factors combined, understanding the interplay among $\mathrm{CO}_{2}$ emissions (SDG 13), economic growth and 
unemployment (SDG 8) income inequality (SDG 10) and energy consumption (SDG 7) is essential to determine whether those SDGs can be achieved in synergy or not. This appears as an important pre-requisite to achieve overall sustainable development goals.

\subsection{Brief Literature Review on Economic Growth and $\mathrm{CO}_{2}$ Emissions}

The relationship between GDP growth and $\mathrm{CO}_{2}$ emissions has been extensively examined by scholars. Overall, the results are inconclusive and point out to a variety of factors that potentially influence such relationship. For example, Narayan and Narayan (2010) tested the Environmental Kuznet's Curve (EKC) hypothesis for 43 developing countries, based on short- and long-run income elasticities. They posited that if long-run income elasticity is smaller than short-run income elasticity, then the country has reduced $\mathrm{CO}_{2}$ emissions as its income has increased. Their empirical results based on individual countries suggest that for South Africa, long-run income elasticity is smaller than short-run elasticity, meaning that $\mathrm{CO}_{2}$ emissions have fallen as South Africa's economy has grown. Later, Narayan et al. (2016) investigated the relationship between GDP growth and $\mathrm{CO}_{2}$ emissions using cross-correlation estimates approach. They posited that if there is a positive cross-correlation between the current income level and future $\mathrm{CO}_{2}$ emissions, then $\mathrm{CO}_{2}$ emission will decline with an increase in income over time, consistent with EKC hypothesis. They found a clear evidence supporting the EKC hypothesis in 21 out of 181 countries, including South Africa. They also found that in 49 countries that include South Africa, income growth will reduce $\mathrm{CO}_{2}$ emissions in the future.

\subsection{Brief Literature Review on Energy Consumption and $\mathrm{CO}_{2}$ Emissions}

Energy consumption is considered as an important driver of $\mathrm{CO}_{2}$ emissions and has been constantly investigated in the empirical literature. For example, Bekun et al. (2019) explored the energy use and economic growth nexus in South Africa from 1960 to 2016 while accounting for capital, labor, and $\mathrm{CO}_{2}$ emissions and found a unidirectional causality from energy consumption to $\mathrm{CO}_{2}$ emissions. On the other hand, Sarkodie and Strezov (2019) examined the effect of foreign direct investment inflows, GDP growth, and energy consumption on greenhouse gas (GHG) emissions from 1982 to 2016 for the top five emitters of GHG, namely; China, India, Iran, Indonesia and South Africa. The study employed among others a panel data regression with Driscoll-Kraay standard errors and found a strong positive effect of energy consumption on GHG emissions and confirmed the validity of the pollution haven hypothesis.

\subsection{Brief Literature Review on Income Inequality and $\mathrm{CO}_{2}$ Emissions}

To our knowledge, there is no study specifically looking at the relationship between income inequality and $\mathrm{CO}_{2}$ emissions in South Africa. However, some studies have incorporated South Africa as part of a panel sample. This is the case for Grunewald et al. (2017) who investigated the link between income inequality and per capita $\mathrm{CO}_{2}$ emissions using a panel data covering 158 countries from 1980 to 2008. Using a superior group fixed effects estimator, they found that the relationship between income inequality and per capita $\mathrm{CO}_{2}$ emissions depends on the level of income. For upper-middle-income economies like South Africa, higher income inequality increases per capita $\mathrm{CO}_{2}$ emissions. Conversely, Ali et al. (2016) used heterogeneous panel ARDL techniques in selected African countries including South Africa from 1984-2001 and found that the relationship between income inequality and $\mathrm{CO}_{2}$ emissions is negative and statistically significant, meaning that widening income inequality could lead to the reduction of $\mathrm{CO}_{2}$ emissions.

\subsection{Brief Literature Review on Unemployment and $\mathrm{CO}_{2}$ Emissions}

There is a dearth of empirical research on the relationship between unemployment and $\mathrm{CO}_{2}$ emissions in the context of Africa in general and South Africa in particular. Alton et al. (2014) are amongst the few scholars to partially address this concern. Alton et al. (2014) evaluated the potential impact on introducing a carbon tax of $\$ 30$ per ton of $\mathrm{CO}_{2}$ emissions using a dynamic economywide model linked to an energy sector model. The results suggest that relative to a baseline with free disposal of $\mathrm{CO}_{2}$, constant world prices and no change in trading partner behavior, the preferred tax scenario reduces national welfare and employment by about 1.2 and 0.6-percent, respectively. If trading partners unilaterally impose a carbon consumption tax on South African exports, then welfare/employment losses exceed those from a domestic carbon tax. Alton et al. (2014) conclude that South Africa can lessen welfare/employment losses by introducing its own border carbon adjustments. The mode for recycling carbon tax revenues strongly influences distributional outcomes, with tradeoffs between growth and equity. Similar studies have been conducted in other avenues such as British Columbia in Canada where a revenue-neutral carbon tax was implemented in 2008. Using workers rather than industries as the unit of analysis, Yip (2018) estimated the labor market consequences of this environmental tax and how such effects are distributed across demographic groups. He found that environmental taxes, though revenue-neutral, tax away jobs disproportionately, more likely from less-educated workers. In particular, the policy increases the 
unemployment rates of medium- and low-educated males by 1.4 and 2.4 percentage points, respectively.

\section{Econometric Methodology}

As indicated in the introduction, this paper examines the long- and short-run impacts of economic growth and unemployment (SDG 8), energy consumption (SDG 7) and income inequality (SDG10) on $\mathrm{CO}_{2}$ emissions in South Africa over the period 1980-2012 to determine potential synergy/trade-off. We use $\mathrm{CO}_{2}$ emissions $\left(\mathrm{CO}_{2}\right)$ as dependent variable and economic growth (GDP), income inequality (GINI) energy consumption (EC) and unemployment rate (UNE) as independent variables. To address the stationarity properties of the time-series, a unit root test is performed to determine whether the specific time series data for $\mathrm{CO}_{2}$ emissions, GINI, GDP, EC and UNE exhibits stochastic trends. Next, cointegration analyses are performed to examine whether the variables are cointegrated (i.e. whether there are stable long-term equilibrium relationships among them). We then proceed with the selection of the model and the estimation of coefficients. Finally, we conduct several diagnostic and stability tests for the model.

\subsection{Model}

The empirical literature (e.g., see Torras and Boyce, 1998; Grunewald, 2017) suggests that the relationship between $\mathrm{CO}_{2}$ emissions and its major determinants can be represented in linear logarithmic form as follows:

$$
\ln \left(\mathrm{CO}_{2}\right)_{\mathrm{t}}=\alpha_{0}+\beta_{1} \ln (\mathrm{GINI})_{\mathrm{t}}+\beta_{2} \ln (\mathrm{GDP})_{\mathrm{t}}+\beta_{3} \ln (\mathrm{EC})_{\mathrm{t}}+\beta_{4}(\mathrm{UNE})_{\mathrm{t}}+\mu_{\mathrm{t}}
$$

where $\left(\mathrm{CO}_{2}\right)_{\mathrm{t}}$ is $\mathrm{CO}_{2}$ emissions; $(\mathrm{GINI})_{\mathrm{t}}$ is the measure of income distribution; (GDP) ${ }_{\mathrm{t}}$ is the per capita real income; $(\mathrm{EC})_{\mathrm{t}}$ is the total primary energy consumption; $(\mathrm{UNE})_{\mathrm{t}}$ is the unemployment rate; and $\mu_{\mathrm{t}}$ is the error term. The letter $\ln$ in Eq. (1) means natural logarithms. With respect to the signs of coefficients in Eq. (1), if more equal distribution of income causes less (more) pollution, one expects $\beta_{1}$ to be positive (negative) and statistically significant. If $\mathrm{CO}_{2}$ emissions decrease (increase) with higher income level, then the sign of $\beta_{2}$ is expected to be negative (positive) and statistically significant. Similarly, the sign of $\beta_{3}$ is expected to be positive (negative) and statistically significant if $\mathrm{CO}_{2}$ emissions is associated with an increase (decrease) in energy consumption. Finally, if an increase (decrease) in $\mathrm{CO}_{2}$ emissions is associated with an increase (decrease) in unemployment rate, then the sign of $\beta_{4}$ is expected to be positive and statistically significant.

\subsection{Panel Unit Root Test}

The first requirement for the use of cointegration techniques is to verify that the variables are integrated to the order of 0 or 1 . Panel cointegration cannot be applied to variables integrated of order 2, because the computed statistics will not be valid (Kim et al., 2010). We use two panel unit root tests - augmented Dickey-Fuller (ADF) test of Dickey and Fuller (1981) and the Phillips-Perron (1988) unit-root testing procedures - to determine the stationary properties of the variables.

\subsection{Cointegration Methodology}

\section{Bounds test of cointegration}

We use the popular Autoregressive Distributed Lag (ARDL) bounds test proposed by Pesaran et al. (2001) to examine the cointegration relationship between $\mathrm{CO}_{2}$ emissions and its determinants. The econometric advantages of the ARDL bounds test over other cointegration procedures is well-documented and include amongst others: (i) the test of the existence of long-run relationship regardless whether the regressors are purely I(0), purely I(1) or fractionally integrated; (ii) the suitability to small sample size and avoidance of endogeneity problems; and (iii) the ability to test hypotheses on the estimated coefficients in the long-run.

To implement the bounds testing procedure following Pesaran et al. (2001), we need to reformulate Eq. (1) into an ARDL model as follows:

$$
\begin{gathered}
\Delta \ln \left(\mathrm{CO}_{2}\right)_{\mathrm{t}}=\alpha+\sum_{k=1}^{p} \phi k \Delta \ln (C O 2) t-k+\sum_{k=0}^{q} \gamma k \Delta \ln (G I N I) t-k+\sum_{k=0}^{q} \delta k \Delta \ln (G D P) t-k+ \\
\sum_{k=0}^{q} \theta k \Delta \ln (E C) t-k+\sum_{k=0}^{q} \rho k \Delta U N E t-k+\lambda_{1} \ln \left(\mathrm{CO}_{2}\right)_{\mathrm{t}-1}+\lambda_{2} \ln (\mathrm{GINI})_{\mathrm{t}-1}+\lambda_{3} \ln (\mathrm{GDP})_{\mathrm{t}-1}+\lambda_{4} \ln (\mathrm{EC})_{\mathrm{t}-1}+ \\
\lambda_{5}(\mathrm{UNE})_{\mathrm{t}-1}+\varepsilon_{\mathrm{t}}
\end{gathered}
$$

where $\Delta$ is the first difference operator; $\mathrm{p}$ and $\mathrm{q}$ are optimum lag orders; $\varepsilon_{\mathrm{t}}$ is the white noise error term. Other variables are as defined earlier.

Eq. (2) is called an error-correction representation of ARDL model and is well-suited to examine the short- and 
long-run relationships between $\mathrm{CO}_{2}$ emissions and its determinants. The short-run relationship is represented by the coefficients of the summation sign $\Sigma$, whereas the long-run relationship is given by $\lambda \mathrm{s}$. The first step of the ARDL approach is to test the existence of long-run relationship among the variables, using the Fisher test ( $F$-test $)$. The null hypothesis of no cointegration $\left(\mathrm{H}_{0}: \lambda_{1}=\lambda_{2}=\lambda_{3}=\lambda_{4}=\lambda_{5}=0\right)$ is tested against the alternative $\left(\mathrm{H}_{1}: \lambda_{1} \neq \lambda_{2} \neq \lambda_{3} \neq \lambda_{4} \neq \lambda_{5} \neq 0\right)$. The computed $F$-statistic is then compared with two sets of critical values (Note 3$)$ (upper and lower) provided by Pesaran et al. (2001) for a given significance level with and without a time trend. One set of critical values assumes that all variables are I( 0$)$ and the other set assumes that all variables are I(1). If the computed $F$-statistic exceeds the upper critical bounds value, then the null hypothesis is rejected suggesting a long-run relationship. If the $F$-statistic is below the lower critical bounds value, it suggests no cointegration or long-run relationship. Lastly, if the $F$-statistic falls into the bounds, then the test is inconclusive. Once a long-run relationship has been established, the second step is to estimate the short and long-run models of Eq. (2) using an appropriate lag selection criterion such as Akaike information (AIC) or Schwarz Bayesian information criterion (SBIC). If there is a cointegration, the error correction model (ECM) is specified as follows:

$$
\begin{gathered}
\Delta \ln \left(\mathrm{CO}_{2}\right)_{\mathrm{t}}=\alpha+\sum_{k=1}^{p} \phi k \Delta \ln (C O 2) t-k+\sum_{k=0}^{q} \gamma k \Delta \ln (G I N I) t-k+\sum_{k=0}^{q} \delta k \Delta \ln (G D P) t-k+ \\
\sum_{k=0}^{q} \theta k \Delta \ln (E C) t-k+\sum_{k=0}^{q} \rho k \Delta(U N E) t-k+\Psi_{E C T} T_{\mathrm{t}-1}+\xi_{\mathrm{t}}
\end{gathered}
$$

where $\Psi$ is the speed of adjustment parameter and it shows how quickly variables converge to equilibrium and should have a statistically significant coefficient with a negative sign.

\section{Johansen and Juselius cointegration test}

We complement the ARDL bounds test of cointegration with the Johansen and Juselius' (1990) maximum likelihood cointegration test. The Johansen and Juselius' (1990) methodology starts with a vector autoregression (VAR) of order $\mathrm{p}$ given by:

$$
\mathrm{Y}_{\mathrm{t}}=\mu+\mathrm{A}_{1} \mathrm{Y}_{\mathrm{t}-1}+\ldots . .+\mathrm{A}_{\mathrm{p}} \mathrm{Y}_{\mathrm{t}-\mathrm{p}}+\varepsilon_{\mathrm{t}}
$$

where $Y_{t}$ is an $n x 1$ vector of variables that are integrated of order one $I(1) ; \varepsilon_{t}$ is the residual matrix, and $\mu$ is a vector of constant terms. This VAR can be re-written as follows:

where

$$
\Delta \mathrm{Y}_{\mathrm{t}}=\mu+\Pi \mathrm{Y}_{\mathrm{t}-1}+\sum_{i=1}^{p-1} \cdot \Gamma_{\mathrm{i}} \Delta \mathrm{Y}_{\mathrm{t}-\mathrm{i}}+\varepsilon_{\mathrm{t}}
$$

$$
\Pi=\sum_{i=1}^{p} . \mathrm{A}_{\mathrm{i}}-\mathrm{I} \text { and } \Gamma_{\mathrm{i}}=-\sum_{j=i+1}^{p} . \mathrm{A}_{\mathrm{j}}
$$

If the coefficient matrix $\Pi$ has reduced rank $\mathrm{r}<\mathrm{n}$, then there are $\mathrm{n} \mathrm{x}$ r matrices $\alpha$ and $\beta$ each with rank $\mathrm{r}$ such that $\Pi=\beta^{\prime} \alpha$ and $\beta^{\prime} Y_{t}$ is stationary. $r$ is the number of cointegrating relationships; the elements of $\alpha$ are the adjustment parameters in the VAR model and each column of $\beta$ is a cointegrating vector. Johansen and Juselius (1990) propose two different likelihood ratio tests of significance of these canonical correlations, namely the trace test and maximum eigen value test, and ultimately the reduced cointegration rank of the coefficient matrix. The trace test tests the null hypothesis of $r$ cointegrating vectors against the alternative hypothesis of $n$ cointegrating vectors. The maximum eigenvalue test tests the null hypothesis of $r$ cointegrating vectors against the alternative hypothesis of $1+\mathrm{r}$ cointegrating vectors. All the variables in Eq. (5) are potentially endogenous and the lag length of the unrestricted VAR is selected based on either AIC, SBIC, HQIC or FPE and the adjusted likelihood ratio test.

\subsection{Model Diagnostic and Stability Tests}

Bahmani-Oskooee and Chomsisengphet (2002) argued that the existence of cointegration derived from Eq. (2) does not necessarily imply that the estimated coefficients are stable. The diagnostic and stability tests of the model are performed by means: (1) Jarque and Bera (1987) test to test the normality of our sample data; (2) White (1980) test to test for constant variance or heteroskedasticity; (3) Brown et al. (1975) tests known as cumulative sum (CUSUM) and cumulative sum of squares (CUSUMSQ) used to measure the goodness of fit of the ARDL model. The coefficients of a given regression are stable if the plots of the CUSUM and CUSUMSQ statistics fall inside the critical bounds of 5-percent significance; (4) Ramsey (1969) test to test the specification of the model. The model is deemed mis-specified if the combinations of explanatory variables have any power in explaining the response variable; (5) Durbin and Watson (1951) test to detect the presence of autocorrelation at lag 1 in the residuals from the regression analysis. 


\section{The Data}

We estimate Eq. (2) using data from South Africa over the period 1980-2012. This period has been chosen based on availability of the data for all the series. $\mathrm{CO}_{2}$ emissions is measured in kg per 2010 US\$ of GDP. GDP is measured as constant 2010 US\$ used as a proxy for income. Both variables are collected from the World Development Indicators (WDI) provided by the World Bank. The GINI coefficient is used as a proxy for income inequality and is obtained from the Standardized World Income Database version 7.1 (SWIID) of the University of Iowa. It ranges from zero (perfect equality) to one (all income received by one individual). The SWIID provides four series of estimates: net income inequality (post-tax, post-transfer); market income inequality (pre-tax, pre-transfer); absolute redistribution (market-income inequality minus net-income inequality) and relative redistribution (market-income inequality minus net-income inequality, divided by market-income inequality). In this study we only use net income inequality because we are more interested in the effect of redistributive policies. Data on energy consumption is collected from the South African's data portal and measured in Quadrillion Btu. Unemployment rate is measured as a percentage of total labor force and collected from the International Monetary Fund (IMF) World Economic Outlook (WEO) database.

\section{Empirical Results and Discussions}

Table 1. Summary statistics

\begin{tabular}{lccccc}
\hline Variable & Obs & Mean & Std. Dev. & Min & Max \\
\hline $\ln \mathrm{CO}_{2}$ & 33 & 0.15 & 0.04 & 0.07 & 0.21 \\
$\operatorname{lnGINI}$ & 33 & 1.76 & 0.01 & 1.75 & 1.77 \\
$\operatorname{lnGDP}$ & 33 & 11.4 & 0.10 & 11.3 & 11.6 \\
$\operatorname{lnEC}$ & 33 & 0.62 & 0.10 & 0.33 & 0.77 \\
$\mathrm{UNE}$ & 33 & 20.4 & 5.18 & 9.24 & 27.8 \\
\hline
\end{tabular}

\subsection{Results of Panel Unit Root Tests}

The first requirement for the use of ARDL is that none of the variables is I(2) or beyond. Henceforth, we started our analysis by testing the presence of a unit root in the variables, using an augmented Dickey-Fuller (ADF) test of Dickey and Fuller (1981) and the Phillips-Perron (1988) unit-root testing procedures. The results presented in Table 2 and Table 3 show that in both cases, each selected series is nonstationary in its level form and stationary in its first difference form. This suggests that our five variables are integrated at order one, i.e., I(1), hence the ARDL modeling can be pursued on them.

Table 2. Results of ADF unit root test

\begin{tabular}{|c|c|c|c|c|c|c|}
\hline \multirow{3}{*}{ Variable } & \multicolumn{6}{|c|}{ ADF test statistic } \\
\hline & \multicolumn{3}{|c|}{ Level } & \multicolumn{3}{|c|}{ First difference } \\
\hline & Statistic & $\mathrm{p}$-value & $\mathrm{k}$ lag & Statistic & $\mathrm{p}$-value & $\mathrm{k}$ lag \\
\hline $\operatorname{lnCO} 2$ & -1.57 & 0.497 & 1 & -4.10 & 0.001 & 0 \\
\hline $\operatorname{lnGINI}$ & -1.79 & 0.384 & 3 & -3.23 & 0.018 & 2 \\
\hline $\operatorname{lnGDP}$ & 1.45 & 0.997 & 1 & -3.46 & 0.009 & 1 \\
\hline $\operatorname{lnEC}$ & -1.08 & 0.722 & 1 & -7.44 & 0.000 & 1 \\
\hline UNE & -2.12 & 0.238 & 4 & -5.99 & 0.000 & 0 \\
\hline
\end{tabular}


Table 3. Results of Phillips-Perron unit root test

\begin{tabular}{|c|c|c|c|c|c|c|}
\hline \multirow{3}{*}{ Variable } & \multicolumn{6}{|c|}{ Phillips-Peron test statistic } \\
\hline & \multicolumn{3}{|c|}{ Level } & \multicolumn{3}{|c|}{ First difference } \\
\hline & Statistic & p-value & $\mathrm{k}$ lag & Statistic & p-value & k lag \\
\hline $\operatorname{lnCO} 2$ & -2.10 & 0.243 & 3 & -5.35 & 0.000 & 3 \\
\hline $\operatorname{lnGINI}$ & -0.55 & 0.881 & 3 & -2.61 & 0.091 & 3 \\
\hline $\operatorname{lnGDP}$ & 1.42 & 0.997 & 3 & -4.24 & 0.001 & 3 \\
\hline $\operatorname{lnEC}$ & -1.35 & 0.602 & 3 & -9.99 & 0.000 & 3 \\
\hline UNE & -2.29 & 0.174 & 3 & -6.2 & 0.000 & 3 \\
\hline
\end{tabular}

\subsection{Results of Cointegration Tests}

As a first stage of the ARDL procedure, we test the existence of a long-run relationship in Eq. (1) in two steps. First, we determined the optimum lag length on the first differenced variables in Eq. (2) from unrestricted VAR by means of Akaike Information Criterion (AIC) and Schwarz Bayesian Criterion (SBC). Second, we performed a bounds $F$-test in Eq. (2) to establish the long-run relationship among the variables. As far as optimum lag selection is concerned, we set the maximum lag to three to minimize the loss of degrees of freedom and found one to be the optimal lag length. The calculated $F$-statistics under the AIC and BIC are found to be 5.60 and 5.48 respectively (see Table 4). These F-statistics both lie above the upper critical value of 4.63 at the 5-percent confidence level provided by Narayan (2005). These results suggest that the null hypothesis of no cointegration can be rejected, thereby confirming the existence of a long-run relationship among the selected variables. We performed a sensitivity check of the ARDL bounds test of cointegration results by means of the Johansen and Juselius' (1990) maximum likelihood cointegration approach. The Johansen System Cointegration Test is performed with no deterministic trend at the optimum lag of one. The results under the Trace test (Table 5.a) indicate the existence of two cointegrating equations at the 0.05 confidence level, whereas the results under the Max-eigenvalue test (Table 5.b) suggest the existence of one cointegrating equation at the 0.05 confidence level. These results are consistent with those of the bounds F-test, all suggesting the existence of cointegration among the variables.

Table 4. Results of the Bound-test of cointegration

\begin{tabular}{|c|c|c|}
\hline Equation & Model & F-statistic \\
\hline \multirow{2}{*}{$\operatorname{lnCO_{2}}=f(\operatorname{lnGINI}, \operatorname{lnGDP}, \operatorname{lnEC}, \mathrm{UNE})$} & AIC $\left(\begin{array}{lllll}1 & 0 & 0 & 1 & 0\end{array}\right)$ & 5.60 \\
\hline & SBC $\left(\begin{array}{lllll}1 & 0 & 0 & 0 & 0\end{array}\right)$ & 5.48 \\
\hline Narayan (2005) & \multicolumn{2}{|c|}{$\mathrm{K}=4, \mathrm{n}=33$} \\
\hline Critical value & Lower bound value & Upper bound value \\
\hline $1 \%$ & 4.59 & 6.368 \\
\hline $5 \%$ & 3.276 & 4.63 \\
\hline $10 \%$ & 2.696 & 3.898 \\
\hline
\end{tabular}

Critical value ranges of F-statistics with four explanatory variables and 33 observations are 4.59-6.37, 3.28-4.63, 2.70-3.90 at 1\%, 5\% and 10\% respectively. See Narayan (2005)'s Table Case III: Unrestricted intercept and no trend. 
Table 5a. Johansen and Juselius' maximum likelihood cointegration results (unrestricted cointegration rank test Trace)

\begin{tabular}{lcccc}
\hline Hypothesized no. of cointegrating equation(s) & Eigenvalue & $\begin{array}{c}\text { Trace } \\
\text { statistic }\end{array}$ & 5\% critical value & Prob. ${ }^{* *}$ \\
\hline None ${ }^{*}$ & 0.84 & 117.35 & 76.97 & 0.00 \\
At most $1 *$ & 0.60 & 60.32 & 54.08 & 0.01 \\
At most 2 & 0.36 & 32.07 & 35.19 & 0.10 \\
At most 3 & 0.34 & 18.24 & 20.26 & 0.09 \\
At most 4 & 0.16 & 5.48 & 9.16 & 0.24 \\
\hline
\end{tabular}

* denotes rejection of the hypothesis at the 0.05 level; **MacKinnon-Haug-Michelis (1999) p-values; lags interval (in first differences): 1 to 1

Table 5b. Johansen and Juselius' maximum likelihood cointegration results (unrestricted cointegration rank test Maximum Eigenvalue)

\begin{tabular}{lcccc}
\hline Hypothesized no. of cointegrating equation(s) & Eigenvalue & $\begin{array}{c}\text { Max-Eigen } \\
\text { statistic }\end{array}$ & 5\% critical value & Prob.** \\
\hline None * & 0.84 & 57.03 & 34.81 & 0.00 \\
At most 1 & 0.60 & 28.26 & 28.59 & 0.06 \\
At most 2 & 0.36 & 13.83 & 22.30 & 0.48 \\
At most 3 & 0.34 & 12.76 & 15.89 & 0.15 \\
At most 4 & 0.16 & 5.48 & 9.16 & 0.24 \\
\hline
\end{tabular}

* denotes rejection of the hypothesis at the 0.05 level; **MacKinnon-Haug-Michelis (1999) p-values; lags interval (in first differences): 1 to 1

\subsection{ARDL Model Selection and Coefficients Estimation}

Once cointegration among the variables is confirmed, the next step is to select the ARDL model to estimate the short- and long-run coefficients. From the optimum lag selection, two models were generated using the lag selection criteria AIC and SBC. The short- and long-run results based on the lag selection criteria are reported in Tables 6 and 7. It emerges from these tables that both models provide nearly the same results with regard to coefficient magnitudes and statistical significance. Notwithstanding, we select AIC over SBC for providing the lowest value of the criterion.

In respect to coefficient elasticity, we find that economic growth has a negative and statistically significant impact on $\mathrm{CO}_{2}$ emissions at 1-percent confidence level in the short- and long-run. A 1-percent increase in GDP is associated with 0.59-percent and 0.88-percent decrease in $\mathrm{CO}_{2}$ emissions in the short- and long-run respectively. These results are well illustrated in Fig. 1 and show that the negative impact of economic growth on $\mathrm{CO}_{2}$ emissions improves in the long-run. These results are consistent with Narayan and Narayan (2010) who found that in South Africa $\mathrm{CO}_{2}$ emissions have fallen as South Africa's economy has grown. In a similar case study for the U.S., Baek and Gweisah (2013) found 0.23-percent and 0.35-percent decrease in $\mathrm{CO}_{2}$ emissions in the shortand long-run for a 1-percent increase in GDP. These results suggest a synergy between the promotion of economic growth (SDG 8) and $\mathrm{CO}_{2}$ emissions reduction (SDG 13) in South Africa in the short-and long-run.

Energy consumption is found to have a positive and statistically significant impact on $\mathrm{CO}_{2}$ emissions at 5-percent confidence level in the short-run, and at 1-percent confidence level in long-run. A 1-percent increase in energy consumption leads to 0.25 -percent and 0.60 -percent increase in $\mathrm{CO}_{2}$ emissions in the short- and long-run respectively. These results suggest that the positive impact of energy consumption on $\mathrm{CO}_{2}$ emissions may increase by 3 times in the long-run. These findings are consistent with Bekun et al. (2019) and Sarkodie and Strezov (2019) who respectively found a unidirectional causality from energy consumption to $\mathrm{CO}_{2}$ emissions, and a strong positive effect of energy consumption on GHG emissions in South Africa. For Turkey, Halicioglu (2009) found that 0.78 -percent increase in $\mathrm{CO}_{2}$ emissions for 1-percent increase in commercial energy consumption. These results suggest that a reduction in energy consumption or an increase in energy efficiency 
(SDG 7) through better access to clean energy will reduce $\mathrm{CO}_{2}$ emissions (SDG 13), inferring a synergy between SDG 7 and SDG 13 in the short- and the long-run, while also emphasizing the need for an energy transition in South Africa to sustain low-carbon economy growth.

The estimated coefficients on income inequality are found to be positive but neither statistically significant at 1-percent, 5-percent nor 10-percent confidence levels in the short- and the long-run. These results differ from either Grunewald et al. (2017) who found that higher income inequality increases per capita $\mathrm{CO}_{2}$ emissions in upper-middle-income economies (e.g., South Africa) or Ali et al. (2016) who found that widening income inequality could lead to the reduction of $\mathrm{CO}_{2}$ emissions in a panel of Sub-Saharan African countries that included South Africa. This difference may be explained by the use of time series analysis in this study in opposition to panel data analysis for the other studies. Our results suggest that there is no relationship, meaning that there is neither synergy nor trade-off between the reduction of income inequality (SDG 10) and the reduction of $\mathrm{CO}_{2}$ emissions (SDG 13). Therefore, the relationship between SDG 10 and SDG 13 is neutral in the short-and long-run, meaning that South Africa can pursue both policies without concern of potential interference.

The short- and long-run coefficients on unemployment rate suggest a negative and statistically significant impact on $\mathrm{CO}_{2}$ emissions. A 1-unit increase in unemployment rate results in 0.3-percent and 0.4-percent decrease in $\mathrm{CO}_{2}$ emissions at 10-percent confidence level. These results suggest that the negative impact of unemployment on $\mathrm{CO}_{2}$ emissions strengthens in the long-run. These results are consistent with Alton et al. (2014) who found that a policy that introduces a carbon tax of $\$ 30$ per ton of $\mathrm{CO}_{2}$ emissions will reduce employment by about 0.6-percent in South Africa. A study by Yip (2018) in the case of British Columbia in Canada also found similar results. Yip (2018) found that carbon tax increases the unemployment rates of medium- and low-educated males by 1.4 and 2.4 percentage points, respectively. Therefore, our results reinforce the argument of $\boldsymbol{a}$ trade-off between reducing unemployment rate or achieving productive employment and decent work (SGD 8) and mitigating $\mathrm{CO}_{2}$ emissions ( $\mathrm{SDG}$ 13) in the short- and long-run in the context of South Africa.

Finally, the error-correction term under the AIC model is found to be -0.66 and significant at 1-percent level, confirming the existence of a long-run relationship between $\mathrm{CO}_{2}$ emissions and its determinants. It suggests that when $\mathrm{CO}_{2}$ emissions is above or below its equilibrium level, it adjusts by almost 66-percent within the first year. This speed of adjustment appears to be significantly fast in the case of any shock to the $\mathrm{CO}_{2}$ emissions equation and supports the argument that there is little control over the increase in $\mathrm{CO}_{2}$ emissions.

We conducted several diagnostic and stability tests to ascertain the goodness of the fit of the ARDL model. Diagnostic tests on the short-run model pass a series of standard diagnostic tests such as serial correlation, functional form specification, heteroskedasticity and normality (see Table 6). In addition, we used the cumulative sum (CUSUM) and cumulative sum of squares (CUSUMSQ) tests to test for the structural stability of our models. The results (see Figs 2 and 3) show that the estimated coefficients are generally stable over the sample period. Therefore, the ARDL model used in this study is well-defined and provides robust findings.

Table 6. Short-run coefficient estimates and diagnostic tests

\begin{tabular}{|c|c|c|c|c|}
\hline \multirow{3}{*}{ Variable } & \multicolumn{4}{|c|}{ Model } \\
\hline & \multicolumn{2}{|c|}{ AIC $\left(\begin{array}{lllll}1 & 0 & 0 & 1 & 0\end{array}\right)$} & \multicolumn{2}{|c|}{$\mathrm{BIC}\left(\begin{array}{lllll}1 & 0 & 0 & 0 & 0\end{array}\right)$} \\
\hline & Statistic & p-value & Statistic & $\mathrm{p}$-value \\
\hline$\Delta \operatorname{lnCO}_{2}(\mathrm{~L} 1)$ & 0.34 & 0.051 & 0.44 & 0.003 \\
\hline$\Delta \operatorname{lnGINI}$ & 1.34 & 0.332 & 1.10 & 0.421 \\
\hline$\Delta \operatorname{lnGDP}$ & -0.59 & 0.008 & -0.42 & 0.010 \\
\hline$\Delta \operatorname{lnEC}$ & 0.25 & 0.036 & 0.23 & 0.051 \\
\hline$\Delta \ln \mathrm{EC}(\mathrm{L} 1)$ & 0.14 & 0.240 & & \\
\hline$\Delta \mathrm{UNE}$ & -0.003 & 0.076 & -0.002 & 0.164 \\
\hline $\mathrm{EC}_{\mathrm{t}-1}$ & -0.66 & 0.000 & -0.56 & 0.000 \\
\hline Serial correlation & 2.45 & 0.118 & 3.11 & 0.078 \\
\hline Heteroskedasticity & 30.10 & 0.310 & 26.61 & 0.147 \\
\hline Functional form & 0.41 & 0.750 & 0.82 & 0.497 \\
\hline Normality & 2.24 & 0.327 & 1.31 & 0.521 \\
\hline
\end{tabular}


Table 7. Long-run coefficient estimates

\begin{tabular}{|c|c|c|c|c|}
\hline \multirow{3}{*}{ Variable } & \multicolumn{4}{|c|}{ Model } \\
\hline & \multicolumn{2}{|c|}{ AIC $\left(\begin{array}{lllll}1 & 0 & 0 & 1 & 0\end{array}\right)$} & \multicolumn{2}{|c|}{ SBC $\left(\begin{array}{lllll}1 & 0 & 0 & 0 & 0\end{array}\right)$} \\
\hline & Statistic & $\mathrm{p}$-value & Statistic & p-value \\
\hline $\operatorname{lnGINI}$ & 2.01 & 0.348 & 1.98 & 0.441 \\
\hline $\operatorname{lnGDP}$ & -0.88 & 0.001 & -0.76 & 0.005 \\
\hline $\operatorname{lnEC}$ & 0.60 & 0.004 & 0.42 & 0.021 \\
\hline UNE & -0.004 & 0.072 & -0.003 & 0.192 \\
\hline
\end{tabular}

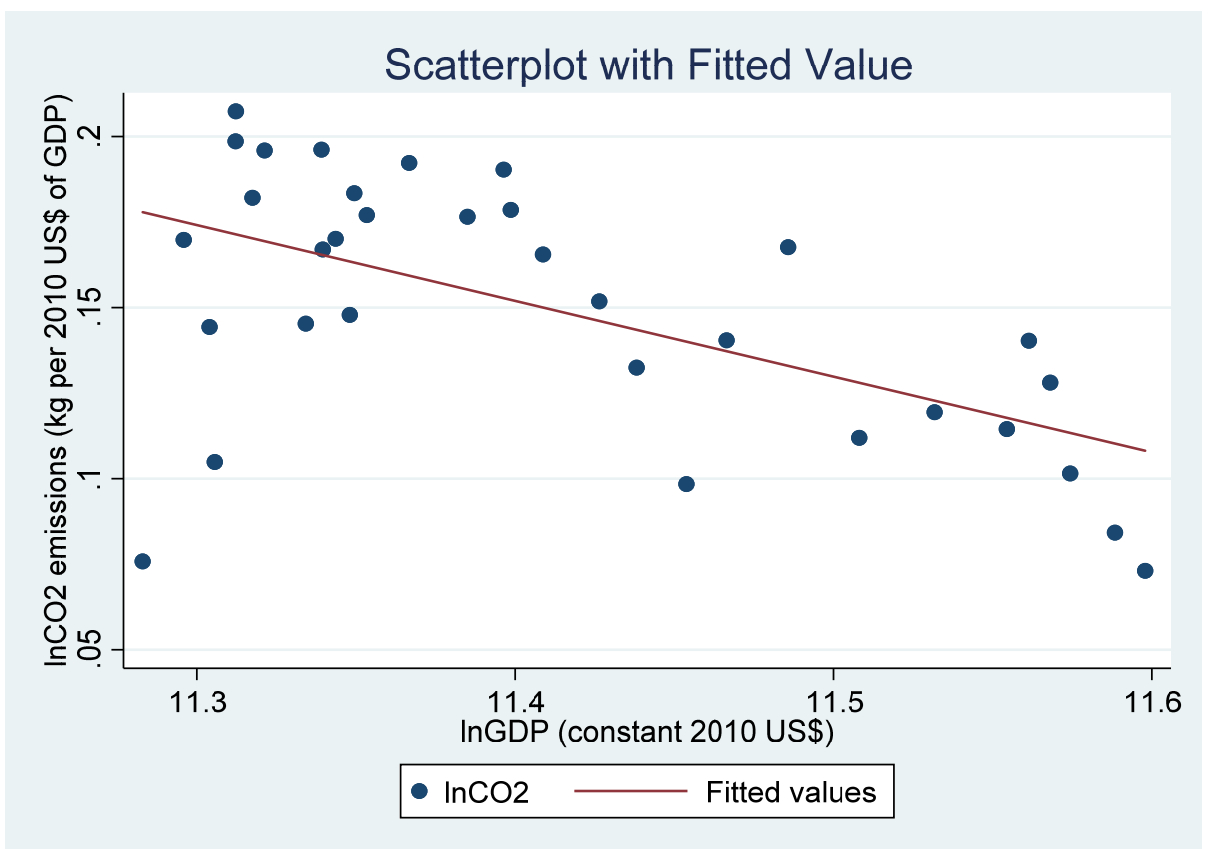

Figure 1. Carbon dioxide emissions and GDP growth in South Africa

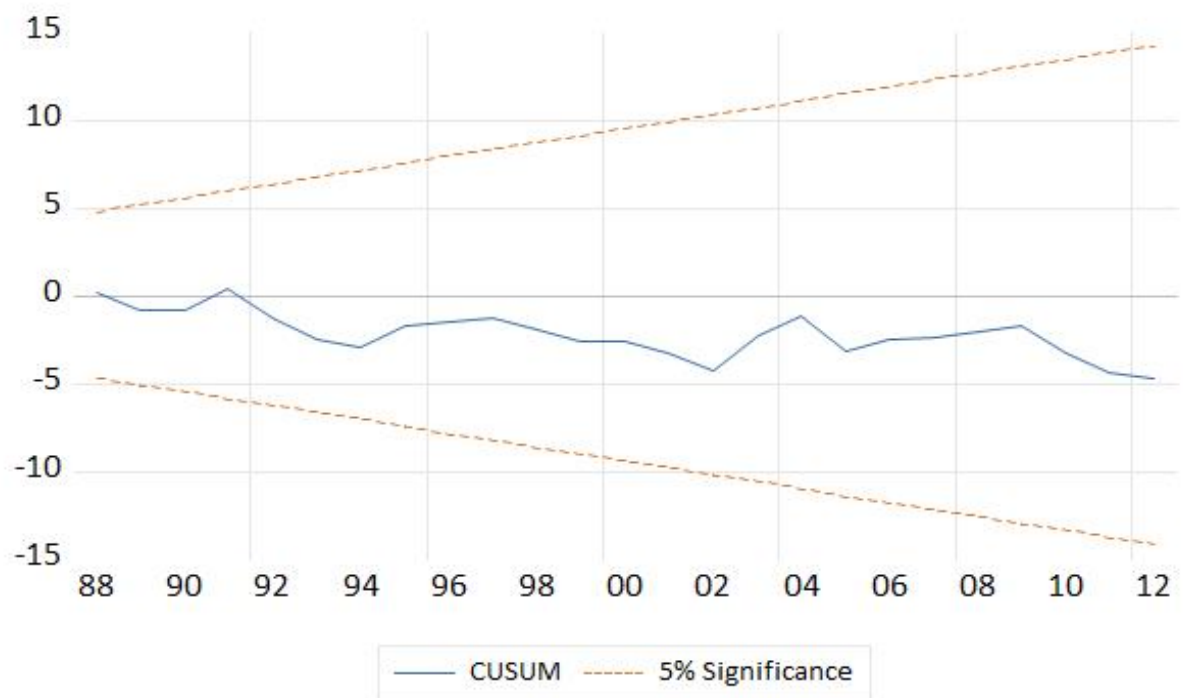

Figure 2. Plot of cumulative sum of recursive residuals 


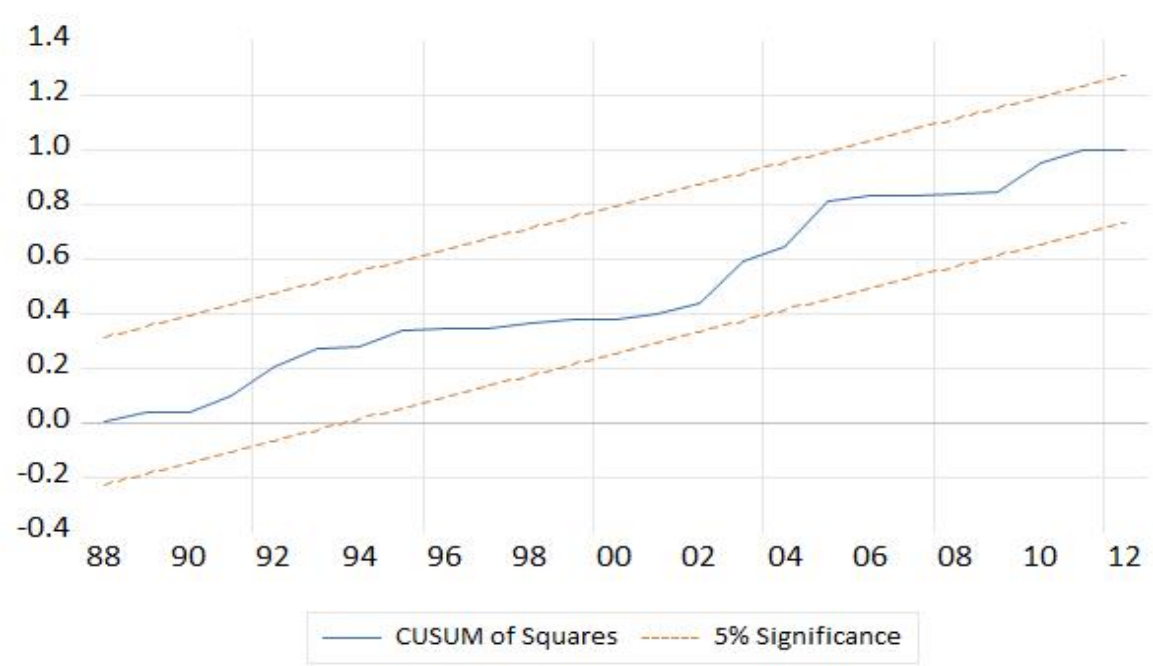

Figure 3. Plot of cumulative sum of square recursive residuals

\section{Conclusion and Policy Implications}

This paper has attempted to examine the long- and short-run impacts of economic growth and unemployment (SDG 8), energy consumption (SDG 7) and income inequality (SDG 10) on $\mathrm{CO}_{2}$ emissions (SDG 13) in South Africa over the period 1980-2012 to establish potential synergy/trade-off. To this aim, we used the autoregressive distributed lag (ARDL) approach to cointegration. Our results show that the pursue of economic growth (SDG 8) and the reduction of $\mathrm{CO}_{2}$ emissions (SDG 13) can be achieved in synergy in the short- and long-run. The same results apply between the reduction in energy consumption/increase in energy efficiency (SDG 7) and the reduction of $\mathrm{CO}_{2}$ emissions ( $\mathrm{SDG}$ 13). On the other hand, we found a trade-off between reducing unemployment rate or achieving productive employment and decent work (SDG 8) and mitigating $\mathrm{CO}_{2}$ emissions (SDG 13) in the short- and long-run. Furthermore, neither synergy nor trade-off (neutral relationship) is found between the reduction of income inequality (SDG 10) and the reduction of $\mathrm{CO}_{2}$ emissions (SDG 13).

These findings are in most part consistent with the current empirical literature and lead to some important policy implications. Our results clearly establish the existence of interactions, such as synergy and trade-off - and eventually a neutral relationship - among sustainable development goals in general, and between SDG 13 and SDG 7, and between SDG 13 and SDG 8. This suggests the need for policymakers to mainstream such interactions in policy making. In addition, based on the energy-induced GDP growth validated by other studies for South Africa (e.g., Bekun et al., 2019), our findings stress the potential for South Africa to achieve low-carbon development should economic growth be decoupled from carbon-intensive energy use through policies that promote access and effective use of clean energy sources. The transition to clean energy is therefore emphasized and relevant factors underpinning such as transition should be explored further.

\section{References}

Ali, H. S., Hassan, S., \& Kofarmata, Y. I. (2016). Dynamic impact of income inequality on carbon emissions in Africa: New evidence from heterogenous panel analysis. International Journal of Energy Economics and Policy, 6(4), 760-766.

Baek, J., \& Gweisah, G. (2013). Does income inequality harm environment? Empirical evidence from the United States. Energy Journal, 62, 1434-1437. https://doi.org/10.1016/j.enpol.2013.07.097

Bahmani-Oskooee, M., \& Chomsisengphet, S. (2002). Stability of M2 money demand function in industrial countries. Applied Economics, 34, 2075-2083. https://doi.org/10.1080/00036840210128744

Bekun, F. V., Emir, F., \& Sarkodie, S. A. (2019). Another look at the relationship between energy consumption, carbon dioxide emissions, and economic growth in South Africa. Science of the Total Environment, 655, 759-765. https://doi.org/10.1016/j.scitotenv.2018.11.271

Boyce, J. K. (1994). Inequality as a cause of environmental degradation. Ecol. Econ., 11(3), 169-178. https://doi.org/10.1016/0921-8009(94)90198-8 
Brown, R. I., Durbin, J., \& Evans, J. M. (1975). Techniques for testing the consistency of regression relations over time. J Roy Statistical Society, 35, 149-192. https://doi.org/10.1111/j.2517-6161.1975.tb01532.x

Dickey, A. D., \& Fuller, W. A. (1981). Likelihood ratio statistics for autoregressive time series with a unit root. Econometrica, 49(4), 1057-1072. https://doi.org/10.2307/1912517

Durbin, J., \& Watson, G. S. (1951). Testing for serial correlation in least squares regression. II. Biometrika, 38(1/2), 159-177. https://doi.org/10.1093/biomet/38.1-2.159

Engle, R. F., \& Granger, C. W. J. (1987). Co-integration and error correction: representation, estimation, and testing. Econometrica, 55, 251-76. https://doi.org/10.2307/1913236

Grunewald, N., Klasen, S., Martinez-Zarzoso, I., \& Muris, C. (2017). The trade-off between income inequality and carbon dioxide emissions. Ecological Economics, 142, 249-256. https://doi.org/10.1016/j.ecolecon.2017.06.034

Halicioglu, F. (2009). An econometric study of CO2 emissions, energy consumption, income and foreign trade in Turkey. Energy Policy, 37, 1156-1164. https://doi.org/10.1016/j.enpol.2008.11.012

IPCC. (2018). Special Report on Global Warming of $1.5^{\circ} \mathrm{C}$ (SR15). Summary for Policymakers.

Jarque, C. M., \& Bera, A. K. (1987). A Test for normality of observations and regression residuals. International Statistical Review, 55(2), 163-172. https://doi.org/10.2307/1403192

Johansen, S. (1988). Statistical analysis of cointegration vectors. Journal of Economic Dynamics Control, 12, 231-54. https://doi.org/10.1016/0165-1889(88)90041-3

Johansen, S., \& Juselius, K. (1990). Maximum likelihood estimation and inference on cointegration with applications to the demand for money. Oxford Bulletin of Economic Statistics, 52, 169-210. https://doi.org/10.1111/j.1468-0084.1990.mp52002003.x

Kais, S., \& Hammami, S. (2016). An econometric study of the impact of economic growth and energy use on carbon emissions: Panel data evidence from fifty-eight countries. Renewable and Sustainable Energy Reviews, 59, 1101-1110. https://doi.org/10.1016/j.rser.2016.01.054

Kuznets, S. (1955). Economic growth and income inequality. The American Economic Review, 45(1), 1-28.

Narayan, K. P., \& Narayan S. (2010). Carbon dioxide emissions and economic growth: Panel data evidence from developing countries. Energy Policy, 38, 661-666. https://doi.org/10.1016/j.enpol.2009.09.005

Narayan, K. P., Saboori, B., \& Soleymani, A. (2016). Economic growth and carbon emissions. Economic Modelling, 53, 388-397. https://doi.org/10.1016/j.econmod.2015.10.027

Nilsson, M., Griggs, D., \& Visbeck, M. (2016). Policy: Map the interactions between sustainable development goals. Nature, 534, 320-322. https://doi.org/10.1038/534320a

Perron, P. (1997). Further evidence on breaking trend functions in macroeconomic variables. Journal of Econometrics, 80, 355-385. https://doi.org/10.1016/S0304-4076(97)00049-3

Pesaran, M. H., \& Shin, Y. (1998). Generalized impulse response analysis in linear multivariate models. Economics Letters, 58, 17-29. https://doi.org/10.1016/S0165-1765(97)00214-0

Pesaran, M. H., Shin, Y., \& Smith, S. (2001). Bounds testing approach to the analysis of level relationships. Journal of Applied Econometrics, 16, 289-326. https://doi.org/10.1002/jae.616

Pradhan, P., Costa, L., Rybski, D., Lucht, W., \& Kropp, J. P. (2017). A systematic study of Sustainable Development Goal (SDG) interactions. Earth's Future, 5, 1169-1179. https://doi.org/10.1002/2017EF000632

Pradhan, P., Reusser, D. E., \& Kropp, J. P. (2013). Embodied greenhouse gas emissions in diets. PLoS One, 8(5), e62228. https://doi.org/10.1371/journal.pone.0062228

Ramsey, J. B. (1969). Tests for specification errors in classical linear least-squares regression analysis. Journal of the Royal Statistical Society. Series B (Methodological), 31(2), 350-371. https://doi.org/10.1111/j.2517-6161.1969.tb00796.x

Sarkodie, S. A., \& Strezov V. (2019). Effect of foreign direct investments, economic development and energy consumption on greenhouse gas emissions in developing countries. Science of the Total Environment, 646, 862-871. https://doi.org/10.1016/j.scitotenv.2018.07.365

Shahbaz, M., Tiwari, A. K., \& Nasir, M. (2013). The effects of financial development, economic growth, coal 
consumption and trade openness on $\mathrm{CO}_{2}$ emissions in South Africa. Energy Policy, 61, 1452-1459. https://doi.org/10.1016/j.enpol.2013.07.006

Singh, G. G., Cisneros-Montemayor, A. M., Swartz, W., Cheung, W., Guy, J. A., Kenny, T. A., ... Ota, Y. (2018). A rapid assessment of co-benefits and trade-offs among Sustainable Development Goals. Marine Policy, 93, 223-231. https://doi.org/10.1016/j.marpol.2017.05.030

Theresa Alton, T., Arndt, C., Davies, R., Hartley, F., Makrelov, K., Thurlowc, J., \& Ubogu, D. (2014). Introducing carbon taxes in South Africa. Applied Energy, 116, 344-354. https://doi.org/10.1016/j.apenergy.2013.11.034

United Nations Development Programme. (2018). Sustainable Development Goals Knowledge Platform. Retrieved August 30, 2018, from https://sustainabledevelopment.un.org/?menu=1300

White, H. (1980). A heteroskedasticity-consistent covariance matrix estimator and a direct test for heteroskedasticity. Econometrica, 48(4), 817-838. https://doi.org/10.2307/1912934

Winkler, H. (2007). Energy policies for sustainable development in South Africa. Energy for Sustainable Development, 11, 26-34. https://doi.org/10.1016/S0973-0826(08)60561-X

World Bank. (2018). Overcoming poverty and inequality in South Africa: An assessment of drivers, constraints and opportunities.

Yip, C. M. (2018). On the labor market consequences of environmental taxes. Journal of Environmental Economics and Management, 89, 136-152. https://doi.org/10.1016/j.jeem.2018.03.004

\section{Notes}

Note 1. A proxy of sustainable development goal 8 "Decent work and economic growth".

Note 2. A proxy of sustainable development goal 10 "Reducing inequality".

Note 3. The set of critical values for limited data (30-80 observations) are provided by Narayan PK. (2005).

\section{Copyrights}

Copyright for this article is retained by the author(s), with first publication rights granted to the journal.

This is an open-access article distributed under the terms and conditions of the Creative Commons Attribution license (http://creativecommons.org/licenses/by/4.0/). 